\title{
Characterization of mesenchymal stem cells isolated from the adipose tissue of young and old dogs
}

\author{
İrem GÜL SANCAK ${ }^{1}$, Asuman ÖZEN², Alev Gürol BAYRAKTAROĞLU² ${ }^{2}$, Ahmet CEYLAN², \\ Pinar CAN ${ }^{1}$
}

Ankara University, Faculty of Veterinary Medicine, ${ }^{1}$ Department of Surgery, ${ }^{2}$ Department of Histology and Embryology, Ankara, Turkey.

Summary: The use of mesenchymal cells in veterinary medicine is considered to be promising for the treatment of several diseases. Due to adipose mesenchymal stem cells being readily available and the expansion of these cells not incurring any additional cost, the culturing of adipose mesenchymal cells has become a commonly applied method. Adipose mesenchymal cells are known to have a multilineage potential of differentiation. Previous research has demonstrated success in the transplantation of canine adipose mesenchymal cells. This study was aimed at the comparative evaluation of mesenchymal stem cells isolated from adipose tissue samples taken at surgery from 3 old dogs (above 5 years of age) and 3 young dogs (1 to 6-months-old or younger), and at the determination of any differences in the adipogenic, chondrogenic, and osteogenic differentiation potential, differentiation rate, proliferation rate, and characteristics of these cells. Furthermore, a comparison was made for the stem cell potential of the lipoaspirates.

Keywords: Adipose tissue, differentiation, dog, mesenchymal stem cell.

\section{Genç ve yaşlı köpeklerin yağ dokusundan elde edilen mezenkimal kök hücrelerin karakterizasyonu}

Özet: Mezenkimal kök hücrelerin veteriner hekimlik alanında kullanımı birçok hastalığın tedavisi için umut 1şığı olarak görülmektedir. Yağ doku kökenli mezenkimal kök hücrelerin eldesinin kolay olması ve üretiminin ek bir maliyet getirmemesi sebebiyle yağ dokudan kök hücre üretimi en çok kullanılan yöntem olarak karşımıza çıkmaktadır. Yağ doku kökenli hücrelerin multilineage potansiyeline sahip olduğu bilinmektedir. Köpek yağ doku kaynaklı mezenkimal kök hücrelerin başarılı bir şekilde transplante edildiği de daha önceki çalışmalarda da bildirilmiştir. Bu çalışmada 3 adet yaşlı (5 yaş üzeri) ve 3 adet genç (6 ay ve altı) köpekten operasyon sırasında alınan yă̆ doku örneklerinden elde edilen mezenkimal kök hücrelerin karşılaştırılması, adipojenik, kondrojenik ve osteojenik farklılaşma potansiyeli, farklılaşma hızı, üreme hızı ve karakteristik özellikleri yönünden aralarındaki farkların ortaya konulması, lipoaspiratın içerdiği kök hücre potansiyelinin karşılaştırılması amaçlanmıştır.

Anahtar sözcükler: Farklılaşma, köpek, mezenkimal kök hücre, yağ doku

\section{Introduction}

In the last decade, rapid advancements have been achieved in research on the use of stem cell therapy for incurable diseases and in regenerative medicine. The use of stem cell therapy, which is intended for diseases not able to be treated with conventional methods, and the use of the own stem cells of organs, are both becoming widespread $(5,16)$. Today, in veterinary medicine, mesenchymal stem cell-based therapies are used in horses and dogs for the treatment of musculoskeletal diseases, tendon and ligament injuries, and the damage of the cartilage tissue and joints $(2,16,23)$.

Mesenchymal stem cells have been isolated from adipose tissue, tendons, the periodontal ligament, synovial membrane, trabecular bone and bone marrow, embryonic tissues, nervous system, skin, periosteum (14), cartilage tissue (3) and muscles (14). Adipose tissue is a readily available source of stem cells (23). Stem cells isolated from adipose tissue are referred to as adipose stem cells (ASCs) and are fibroblast-like cells with a multilineage differentiation capacity $(2,21,25)$. In human medicine, researches on mesenchymal stem cells are made use of, not only in regenerative medicine, but also in systemic transplantation, combined stem cell therapy and gene therapy, and tissue engineering (25). In humans, adipose mesenchymal stem cells are used as a cell source for the treatment of cardiovascular diseases with cell therapy $(12,18,19)$. The neuronal differentiation of human adipose mesenchymal stem cells suggests that they could be used as an alternative cell source for the treatment of neurological diseases (20). It has also been reported that adipose mesenchymal cells can be used for hepatocyte regeneration and hepatocyte transplantation (22). 
Although positivity for CD44, CD73, CD90, CD105, CD106, CD146, CD166 and negativity for CD14, CD34 and CD45 is expected (1) there is no such specific surface antigen that can identify multipotent stem cells (24).

The ultrastructure and differentiation potential of mesenchymal stem cells isolated from bone marrow have been investigated by transmission electron microscopy (9), and it has been reported that, while these cells are in continuous communication with each other and display a higher number of vacuoles in the contact sites, the substances contained by these vacuoles play a major role in signalization (15). In a study conducted by scanning electron microscopy, it was observed that the cells showed a tendency of contact and extended to each other by means of pseudopodia (17).

In this study, adipose mesenchymal cells isolated from old and young dogs were compared for both differentiation and proliferation rates, so as to determine the impact of age on the differentiation of mesenchymal stem cells.

\section{Materials and Methods}

Adipose tissue, extracted from the inguinal region of healthy dogs under general anaesthesia, constituted the material of the study (Ethics Board Decision HADYEK2014-19-143). The animals were anesthetized with propofol induction $(6.6 \mathrm{mg} \mathrm{kg} \mathrm{BW})$ and isoflurane (1\%) maintenance. The inguinal region was prepared for the operation by observing asepsis and antisepsis rules, and adipose tissue samples of $0.5 \mathrm{~cm}^{3}$ were extracted from the subcutaneous region. The samples were transported to the laboratory in sterile tubes. At the laboratory, the samples were transferred into Dulbecco's modified Eagle's medium (DMEM) (Lonza, Belgium) under laminar flow, and were cut into small pieces in sterile petri dishes. Cell expansion was performed in T25 flasks using the explant culture method. Following incubation in a $5 \% \quad \mathrm{CO}_{2}$ incubator for 15 minutes, a medium containing $20 \%$ foetal bovine serum (Lonza, Belgium), 2\% L-Glutamine (Lonza, Belgium), 10.000 IU 1\% penicillin, streptomycin and amphotericin (Biological Industries, Israel), and 77\% Dulbecco's modified Eagle's medium (DMEM) (Lonza, Belgium), was added. The culture medium was renewed every three days and cell proliferation was observed under an inverted microscope (Olympus Cx45). The flasks, which reached a confluence of $70 \%$, were passaged at a ratio of $1: 2$, and before seeding, the number and viability of the cells were checked and $5 \times 10^{6}$ cells were seeded in each flask. At the end of the third passage, the cells were induced for differentiation into cells of adipogenic, osteogenic and chondrogenic lineage.
Adipocyte differentiation basal medium containing an adipogenic supplement (Gibco, USA) was used to induce adipogenic differentiation. Following the third passage, the culture medium was renewed every three days, and at the end of the $3^{\text {rd }}$ week, the cells were stained with Oil Red-O (Sigma Aldrich - USA - Lot SLBC9102V). Thereby, differentiation into adipocytes was recorded on the basis of the observation of the presence of lipid droplets within the cells under an inverted microscope.

Osteocyte differentiation basal medium (Gibco, USA) was used to induce osteogenic differentiation. Following the third passage, the culture medium was renewed every three days, and at the end of the $3^{\text {rd }}$ week, the cells were stained with Von Kossa solution (Merck, Lot HC392067). Osteogenic cells were observed under an inverted microscope.

Chondrocyte differentiation basal medium (Darmstadt, Germany) was used to induce chondrogenic differentiation. Following the third passage, the culture medium was renewed every three days, and at the end of the $3^{\text {rd }}$ week, the cells were stained with Alcian blue (Millipore-California-USA Lot 2496226) for the observation of chondrocytes by inverted microscopy and the recording of differentiation (23).

\section{Results}

Cell proliferation potential: The comparison of the proliferation potential of the cells isolated from the adipose tissue (Figure 1) of young and old dogs demonstrated that the adipose-derived cells of the young and old dogs had reached $70 \%$ confluence at the $1^{\text {st }}$ passage on day 12 and day 14-15, respectively (Figure 2).

It was observed that, while the cells resembled fibroblasts on day 1 (Figure 3A), their morphology transformed into an oval shape with passaging (Figure $3 \mathrm{~B})$. It was determined that the cells isolated from the young and old dogs acquired an oval shape after 19-20 and 22-23 days, respectively.

Differentiation potential: It was ascertained that, the lipid droplets emerged at an earlier stage of adipogenic differentiation and existed at a higher concentration in the cells isolated from the young animals (Figure 3C), in comparison to the cells isolated from the old animals (Figure 3D). Furthermore, it was determined that the formation of lipid droplets started at the edges of the flasks and advanced towards the centre with the increase of signalization.

Following chondrogenic differentiation, the cells isolated from the young animals were observed to have stained more strongly with Alcian blue (Figure 3E), when compared to the cells isolated from the old animals (Figure 3F). 


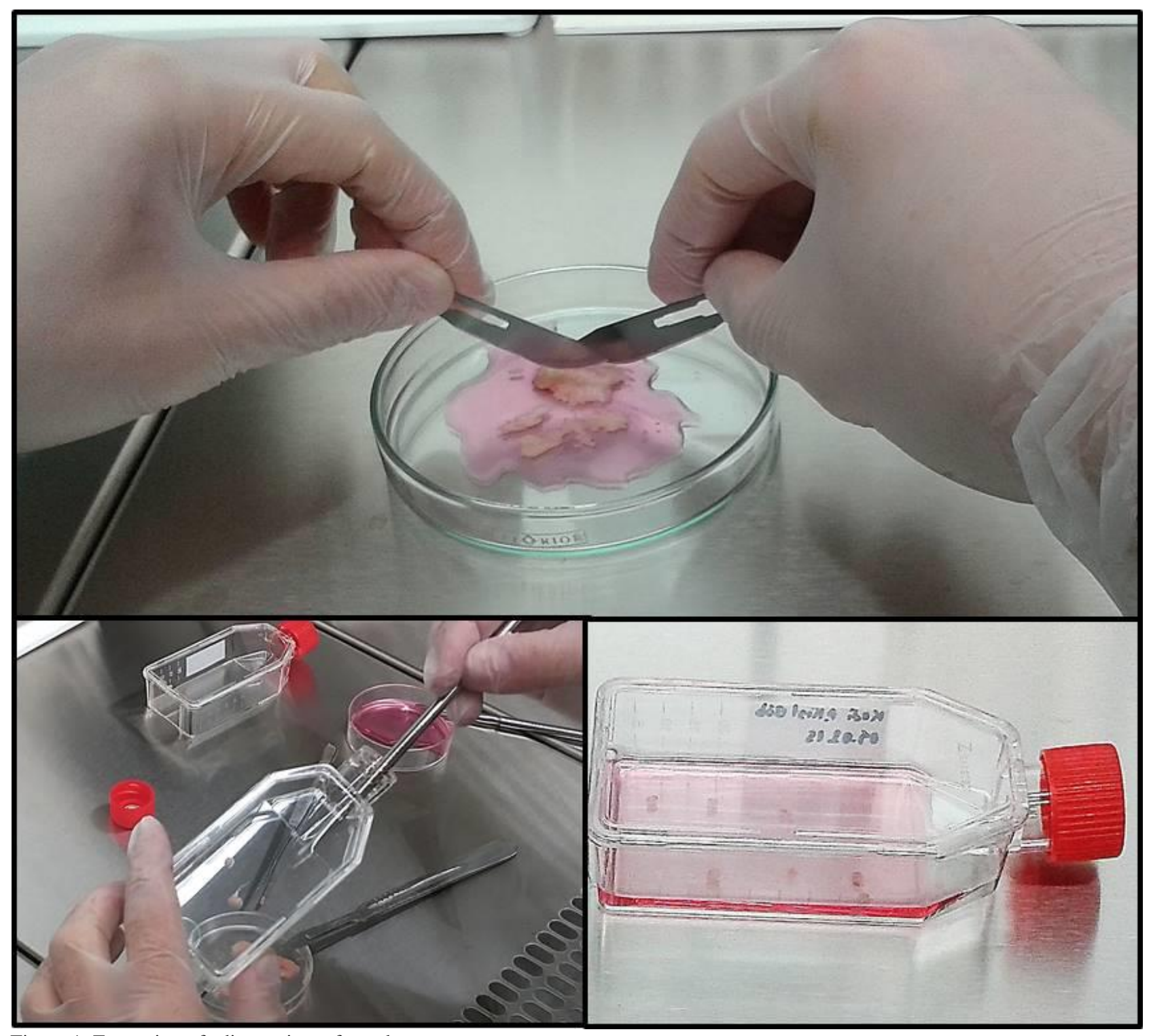

Figure 1: Extraction of adipose tissue from dog.

Şekil 1: Yağ dokusunun köpekten ekstraksiyonu.

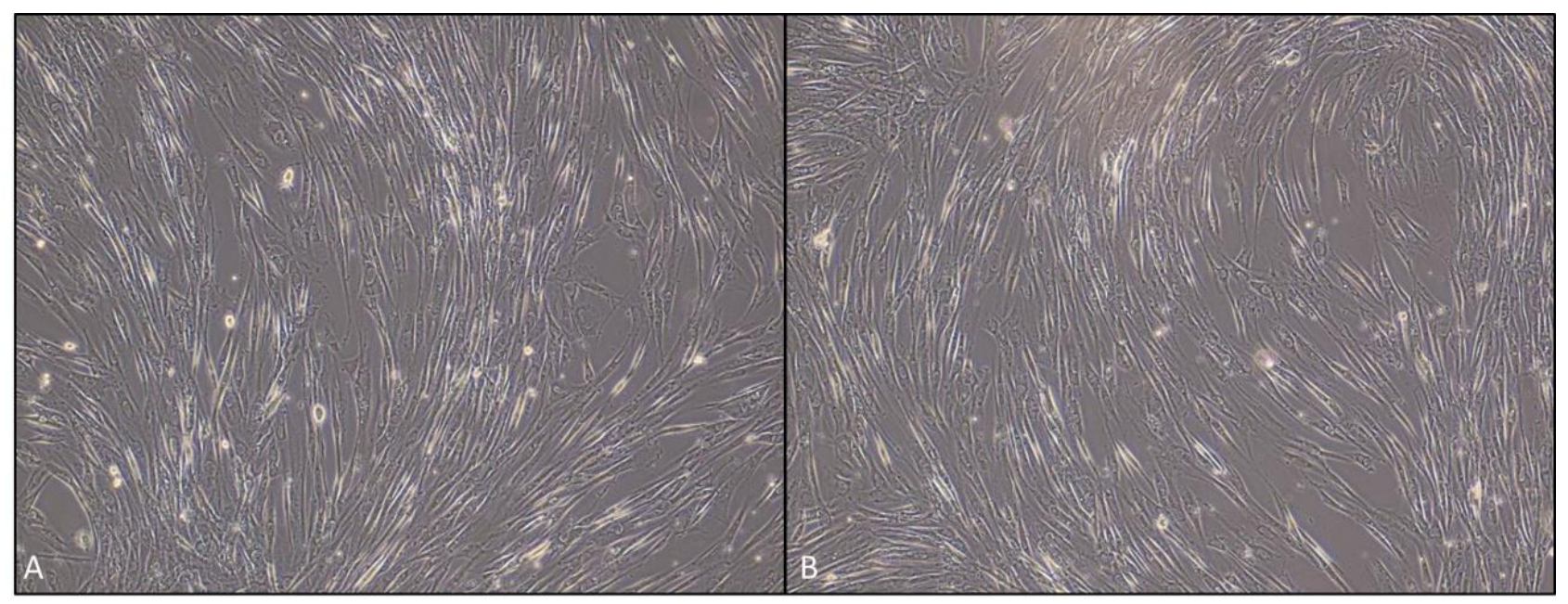

Figure 2: Appearance of a confluent flask. Young dog (A), old dog (B). Şekil 2: Konfluent flask görünümü. Genç köpek (A), yaşlı köpek (B). 

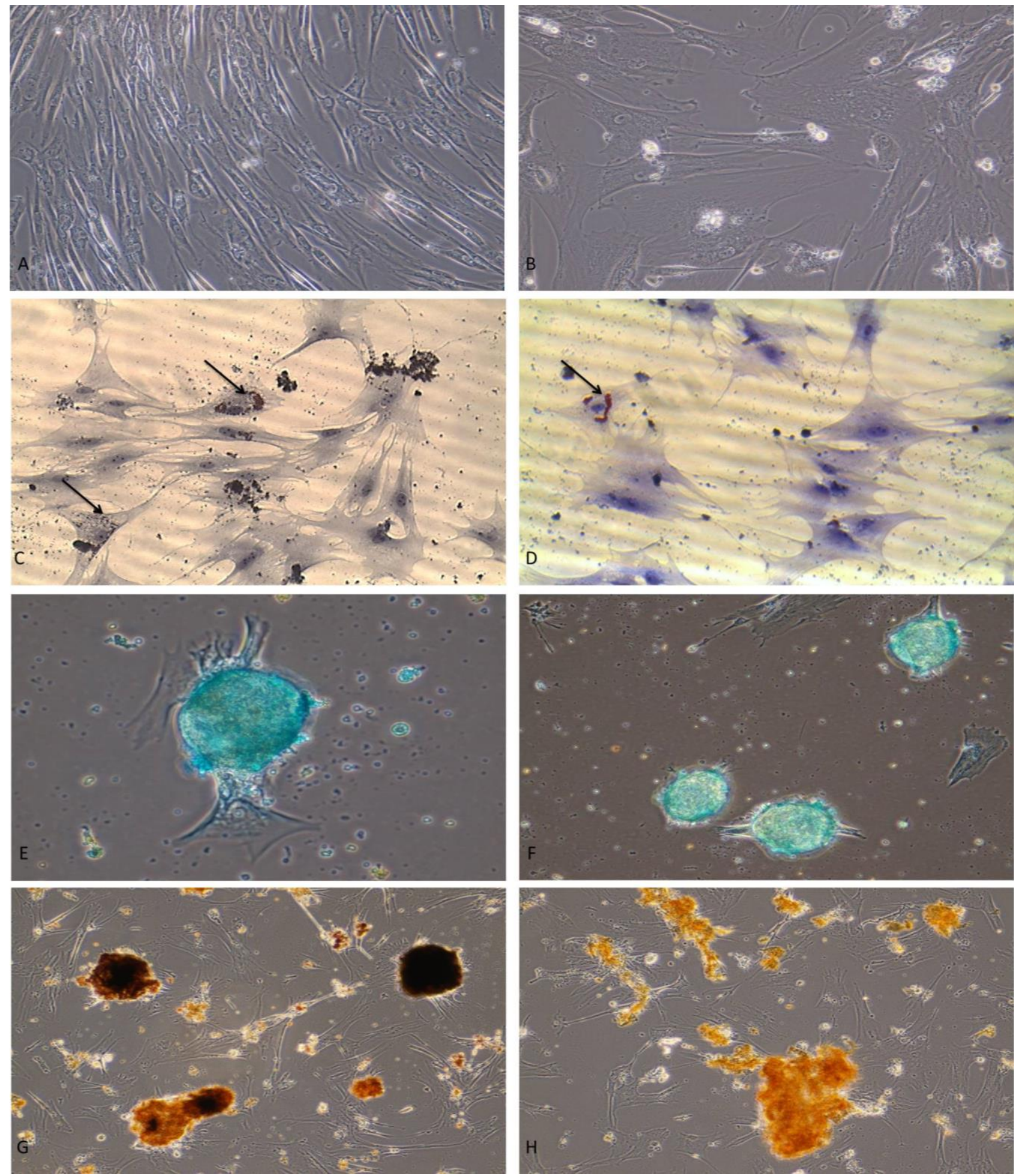

Figure 3: Fibroblast-like cells at early passage (A), oval cell morphology in relation to the number of passages (B); formation of lipid droplets (arrows) during adipogenic differentiation in cells isolated from young dogs (C) and old dogs (D); glycosaminoglycan synthesis during chondrogenic differentiation in cells isolated from young dogs (E) and old dogs (F); demonstration of ossification during osteogenic differentiation by Von Kossa staining in cells isolated from young dogs $(\mathrm{G})$ and old dogs $(\mathrm{H})$.

Şekil 3. İlk pasajdaki fibroblast benzeri hücreler (A), artan pasaj sayısıyla ilişkili hücre morfolojisinde ovalleşme (B), genç (C) ve yaşlı (D) köpeklerde adipojenik farklılaşmadaki hücrelerdeki yağ damlacıklarının (oklar) formasyonu; genç (E) ve yaşlı (F) köpeklerden izole edilen hücrelerde kondrojenik farklılaşmadaki glikozaminoglikan sentezi; genç $(\mathrm{G})$ ve yaşlı (H) köpeklerden izole edilen hücrelerde osteojenik farklılaşmanın Von Kossa boyaması ile gösterimi. 
Similarly, after osteogenic differentiation, the cells isolated from the adipose tissue of the young animals were observed to have stained more strongly with Von Kossa solution (Figure 3G), in comparison to the adipose-derived cells of the old animals (Figure 3H).

\section{Discussion and Conclusion}

The extraction and culturing of adipose tissue cells are relatively easy processes. It has been reported that, in humans, $1 \times 10^{6}$ stem cells can be isolated from $100 \mathrm{ml}$ of adipose tissue (11). In a previous study carried out in dogs, it was reported that an adequate number of stem cells were able to be isolated from $100 \mu$ of adipose tissue (23). In the present study, $0.5 \mathrm{~cm}^{3}$-samples of inguinal adipose tissue were extracted by surgery, and on the basis of cell expansion in flasks, it was found that $0.01 \mathrm{~m}^{3}$ of adipose tissue was adequate for the culturing of stem cells.

The myogenic differentiation of human lipoaspiratederived cells has been investigated, and it has been reported that these cells could be used in the bioengineering of skeletal muscle as well as in regenerative medicine (13). Furthermore, the biochemical, cellular and molecular characterization of human adipose-derived stromal cells has been investigated, and the responses of these cells to differentiation with glucocorticoids and thiazolidinediones have been evaluated. It is considered that adipose-derived stromal cells constitute a reliable model for the assessment of adipocyte metabolism in humans (6). It has been reported that, cultured mesenchymal stem cells isolated from the bone marrow, aided in tissue healing at the operation site of the patellar tendon in surgically treated New Zealand rabbits, and provided evident benefits (7). The comparison of the features of adipocytes derived from the subcutaneous tissue with those of adipocytes originating from the bone marrow demonstrated that cells of subcutaneous origin were part of the stem cell system localized to the bone marrow and various other organs (8). Vieira reported that, during chondrogenic differentiation, the mucopolysaccharide-rich extracellular matrix stained positively as from the third week (23). In the present study, success was achieved in the differentiation of canine adipose mesenchymal stem cells into all three lineages (adipogenic, osteogenic, chondrogenic). The comparison of the differentiation of the adipose-derived cells of the young dogs with the cells isolated from the old dogs showed that differentiation occurred more slowly and at a limited level in the cells of old animals. This was attributed to the decrease in the extracellular matrix of cells with ageing (4).

After being isolated, the cells that were seeded into the flasks were observed to display a fibroblast-like morphology on the $1^{\text {st }}$ day of the culturing process. After the third passage, these cells were determined to have differentiated into adipocytes, osteocytes and chondrocytes, and thus, to display a stem cell phenotype. Vieira et al. reported that, while mesenchymal stem cells were positive for the surface markers CD29, CD44 and CD90, they were negative for CD45, and indicated that the single criterion for these cells to be classified as mesenchymal stem cells is trilinear differentiation (23).

Based on the comparison of human and canine cells undergoing adipogenic differentiation, it has been indicated that lipid vacuoles are observed at a lower level in differentiated canine adipose cells (23). In the present study, the cells isolated from the young and old dogs differed for the number of lipid vacuoles, which was found to be greater in the cells isolated from the young animals.

Adipose mesenchymal stem cells, which were investigated for their proliferation potential in the present study, require further investigation like surface marker expression, as they constitute a significant cell source for use in the clinical treatment of several diseases.

\section{References}

1. Can A (2014): Kök hücre. Akademisyen Tip Kitabevi, Yenişehir, Ankara.

2. Csaki C, Matis U, Mobasheri A, et al. (2007): Chondrogenesis, osteogenesis and adipogenesis of canine mesenchymal stem cells: a biochemical, morphological and ultrastructural study. Histochem Cell Biol, 128, 50720.

3. Diaz-Romero J, Quintin A, Schoenholzer E, et al. (2013): S100A1 and S100B Expression Patterns Identify Differentiation Status of Human Articular Chondrocytes. J Cell Physiol, 229, 1106-1117.

4. Gartner LP, Hiatt JL (1997): Colour textbook of histology. WB Sounders Company, Philadelphia, Pensylvania.

5. Gül Sancak İ, Özen A, Alparslan Pınarlı F, et al. (2014): Limbal Stem Cells in dogs and cats their identification culture and differentiation into keratinocytes. Kafkas Univ Vet Fak Derg, 20, 909-914.

6. Halvorsen YD, Bond A, Sen A, et al. (2001): Thiazolidinediones and glucocorticoids synergistically induce differentiation of human adipose tissue stromal cells: Biochemical, cellular, and molecular analysis. Metabolism, 50, 407-413.

7. Awad HA, Butler DL, Boivin GP, et al. (1999): Autologous Mesenchymal Stem Cell-Mediated Repair of Tendon. Tissue Engineering, 5, 267-277.

8. Justesen J, Pedersen SB, Stenderup K, et al. (2004): Subcutaneous adipocytes can differentiate into boneforming cells in vitro and in vivo. Tissue Eng, 10, 381-391.

9. Karaöz E, Aksoy A, Ayhan S, et al. (2009): Characterization of mesenchymal stem cells from rat bone marrow: ultrastructural properties, differentiation potential and immunophenotypic markers. Histochem Cell Biol, 132, 533-546.

10. Lettry V, Hosoya K, Takagi S, et al. (2010): Coculture of equine mesenchymal stem cells and mature equine 
articular chondrocytes results in improved chondrogenic differentiation of the stem cells. Jpn J Vet Res, 58, 5-15.

11. Meliga E, Strem BM, Duckers HJ, et al. (2007): Adipose-derived cells. Cell Trans, 16, 963-970.

12. Miranville A, Heeschen C, Sengenes C, et al. (2002): Improvement of postnatal neovascularization by human adipose tissue-derived stem cells. Circulation, 110, 349355.

13. Mizuno H, Zuk PA, Zhu M, et al. (2002): Myogenic differentiation by human processed lipoaspirate cells. Plast Reconstr Surg, 109, 199-209.

14. Orbay H, Tobita M, Mizuno H (2012): Mesenchymal Stem Cells Isolated from Adipose and Other Tissues: Basic Biological Properties and Clinical Applications. Stem Cells International Volume, Article ID 461718, 9. http://dx.doi.org/10.1155/2012/461718.

15. Ozen A, Gul Sancak I, Koch S, et al. (2013): Ultrastructural characteristics of sheep and horse mesenchymal stem cells (MSCs). Mic Res, 1, 17-23.

16. Özen A, Gül Sancak İ (2014): Mezenkimal kök hücreler ve veteriner hekimlikte kullanımı. Ankara Üniv Vet Fak Derg, 61, 79-84.

17. Özen A, Gül Sancak İ, Tiryaki M, et al. (2013): Mesenchymal stem cells (Mscs) in scanning electron microscopy (SEM) world. Niche, 2: 22-4. DOI: 10.5152/niche.2013.162

18. Planat-Benard V, Silvestre J S, Cousin B, et al. (2004): Plasticity of human adipose lineage cells toward endothelial cells: Physiological and therapeutic perspectives. Circulation, 109, 656-663.

19. Rehman J, Traktuev D, Li J, et al. (2004): Secretion of angiogenic and antiapoptotic factors by human adipose stromal cells. Circulation, 109, 1292.
20. Safford KM, Hicok KC, Safford SD, et al. (2002): Neurogenic differentiation of murine and human adiposederived stromal cells. Biochem Biophys Res Commun, 294, 371-379.

21. Sarraf CE, Otto WR, Eastwood M (2011): In vitro mesenchymal stem cell differentiation after mechanical stimulation. Cell Prolif. Feb, 44, 99-108.

22. Seo MJ, Suh SY, Bae YC, et al. (2005): Differentiation of human adipose stromal cells into hepatic lineage in vitro and in vivo. Biochem. Biophys. Res. Commun, 328, 258264.

23. Vieira NM, Brandalise V, Zucconi E, et al. (2010): Isolation, Characterization, and Differentiation Potential of Canine Adipose-Derived Stem Cells. Cell Transplantation, 19, 279-289.

24. Yamamoto N, Akamatsu H, Hasegawa S, et al. (2007): Isolation of multipotent stem cells from mouse adipose tissue. J Dermatol Sci, 48, 43-52.

25. Zuk PA, Zhu M, Mizuno H, et al. (2001): Multilineage cells from human adipose tissue: implications for cellbased therapies. Tissue Eng, 7, 211-28.

Geliş tarihi: 24.04.2015 / Kabul tarihi: 27.11.2015

Address for correspondence:

Prof. Dr. Asuman Özen

Ankara University, Faculty of Veterinary Medicine,

Department of Histology and Embryology,

06110 Dışkapı, Ankara-Turkey.

e-mail: ozen@veterinary.ankara.edu.tr 